\title{
PENERAPAN FUNGSI MANAJEMEN PADA KELOMPOK TANI ASI ENDO DI DESA TEWASEN KECAMATAN AMURANG BARAT KABUPATEN MINAHASA SELATAN
}

\author{
Kivry E. Salmon \\ Jenny Baroleh \\ Juliana R. Mandei
}

\begin{abstract}
ABSTRAK
The purpose of this research is to know the implementation of management function in Asi Endo Farmer Group in Tewasen Village, Amurang Barat Subdistrict, South Minahasa Regency. The study was conducted from April to June 2017. The data used were primary data obtained from direct interviews with the management and members of farmer groups based on prepared questions list and direct observation or survey in the research site. Data analysis used is descriptive analysis, presented in tabular form, then the resultant data is analyzed by using likert scale. The results showed that the implementation of Asi Endo farmer group management function in Tewasen Village, Amurang Barat subdistrict of South Minahasa Regency covering the function of planning, organizing function, movement function, supervisory function and assessment function, as a whole is in the Very Good category with $82.8 \%$. This means that group members together with group administrators are very good at implementing management functions within the Asi Endo farmer group. *jrm*
\end{abstract}

Keywords: implementation of management functions, farmer groups, Tewasen Village, Amurang Barat District, South Minahasa District

\begin{abstract}
ABSTRAK
Penelitian bertujuan mengetahui penerapan fungsi manajemen dalam Kelompok Tani Asi Endo di Desa Tewasen, Kecamatan Amurang Barat, Kabupaten Minahasa Selatan. Penelitian dilaksanakan pada bulan April sampai Juni 2017. Data yang digunakan yaitu data primer yang diperoleh dari wawancara langsung dengan pengurus dan anggota kelompok tani berdasarkan daftar pertanyaan yang disiapkan serta hasil pengamatan secara langsung atau survey di tempat penelitan. Analisis data yang digunakan yaitu analisis deskriptif, yang disajikan dalam bentuk tabel, kemudian data yang dihasilkan dianalisis dengan menggunakan skala likert. Hasil penelitian menunjukan bahwa penerapan fungsi manajemen kelompok tani Asi Endo di Desa Tewasen, Kecamatan Amurang Barat, Kabupaten Minahasa Selatan yang meliputi fungsi perencanaan, fungsi pengorganisasian, fungsi penggerakan, fungsi pengawasan dan fungsi penilaian, secara keseluruhan berada pada kategori Sangat Baik dengan hasil 82.8\%. Artinya anggota kelompok bersama dengan pengurus kelompok sangat baik dalam menerapkan fungsi manajemen dalam Kelompok Tani Asi Endo.
\end{abstract}

Kata Kunci: penerapan fungsi manajemen, kelompok tani, Desa Tewasen, Kecamatan Amurang Barat, Kabupaten Minahasa Selatan 


\section{PENDAHULUAN}

\section{Latar Belakang}

Peranan sektor pertanian dalam perekonomian nasional sangat penting dan strategis. Hal ini terutama karena sektor pertanian masih memberikan lapangan pekerjaan bagi sebagian besar penduduk yang ada di pedesaan dan menyediakan bahan pangan bagi penduduk. Semua usaha pertanian pada dasarnya adalah kegiatan ekonomi sehingga memerlukan dasar-dasar pengetahuan yang sama akan pengelolaan tempat usaha, pemilihan benih/bibit, metode budidaya, pengumpulan hasil, distribusi produk, pengolahan, pengemasan produk, dan pemasaran. Besarnya penduduk yang terlibat dalam sektor pertanian serta kemampuannya dalam menghadapi krisis ekonomi yang terjadi saat ini juga merupakan alasan lain sektor pertanian sangat penting untuk dipertahankan dalam pelaksanaan pembangunan nasional di Indonesia.

Dalam proses pencapaian tujuan suatu organisasi, perlu adanya manajemen, karena manajemen merupakan sebuah proses dalam rangka untuk mencapai suatu tujuan organisasi dengan cara bekerja secara bersama sama dengan orang-orang dan sumber daya yang dimiliki organisasi. Artinya, perlu diberikan bimbingan karena tidak semua terampil dalam melaksanakan kegiatan organisasi. Cara yang digunakan untuk membimbing bergantung pada kebijakan dan keinginan pemimpin, seperti pekerja yang kurang terampil diberikan pelatihan untuk meningkatkan kemampuannya. Organisasi/kelompok tani merupakan bagian atau kesatuan dari masyarakat petani yang hidup dan tinggal bersama dalam lingkungan sosial yang terbentuk untuk mencapai suatu tujuan yang didalamnya tidak bekerja secara individu, melainkan secara berkelompok dengan memiliki kesadaran untuk saling tolong menolong. Organisasi/kelompok tani dapat dibentuk secara swadaya oleh masyarakat maupun atas dasar kepentingan kebijakaan dari pemerintah melalui dinas pertanian.

Pengelolaan sumber-sumber daya tentu membutuhkan manajeman yang baik. Untuk mencapai tujuan dari kelompok, maka kelompok tani Asi Endo di Desa Tewasen Kecamatan Amurang Barat Kabupaten Minahasa Selatan pastinya akan menghadapi persoalan yang terkait dengan keterbatasan berbagai unsur sumber daya, seperti sumber daya manusia yang memiliki keterbatasan fisik, modal seringkali kurang, material sebagai bahan baku atau proses produksi bermasalah dengan ketersediaannya, metode sebagai panduan untuk menyelesaikan pekerjaan masih bergantung pada pemahaman dan kemampuan mengolah. Oleh karena itu, kelompok tani sangat memerlukan manajemen untuk mengolah pertanian agar lebih bekembang. Dalam upaya memberdayakan petani diperlukan pengolahan kelompok yang dilakukan dari, oleh dan untuk petani. Dalam manajemen terdapat beberapa fungsi utama yang terdiri dari perencanaan, pengorganisasian, penggerakan, pengawasan dan penilaian. Manajemen sangat diperlukan untuk mengatur kelompok tani dalam melakukan/mengambil keputusan dalam berorganisasi.

Desa Tewasen merupakan salah satu desa yang terletak di daerah Minahasa Selatan tepatnya di Kecamatan Amurang Barat. Desa ini sudah berdiri sejak tahun 1740 atau sekarang berusia 277 tahun. Di desa ini terdapat 20 kelompok tani yang terdaftar dan hanya 3 kelompok tani yang masih aktif sampai sekarang. Dari ketiga kelompok tani yang ada kelompok tani Asi Endo merupakan yang paling terkenal dan masih aktif serta sukses dalam pengerjaannya.

Berdasarkan fenomena tersebut, maka peneliti tertarik untuk meneliti tentang: Penerapan Fungsi Manajemen dalam Kelompok Tani Asi Endo di Desa Tewasen Kecamatan Amurang Barat Kabupaten Minahasa Selatan. 


\section{Rumusan Masalah}

Berdasarkan latar belakang, yang menjadi masalah dalam penelitian ini yaitu: bagaimana penerapan fungsi manajemen pada Kelompok Tani Asi Endo di Desa Tewasen Kecamatan Amurang Barat Kabupaten Minahasa Selatan?

\section{Tujuan Penelitian}

Penelitian ini bertujuan untuk mengetahui penerapan fungsi manajemen dalam Kelompok Tani Asi Endo di Desa Tewasen Kecamatan Amurang Barat Kabupaten Minahasa Selatan.

\section{Manfaat Penelitian}

Penelitian ini diharapkan bermanfaat:

1. Sebagai bahan informasi untuk Kelompok Tani Asi Endo dan kelompok tani lainnya serta masyarakat Desa Tewasen Kecamatan Amurang Barat dalam proses pengembangan kelompok tani di Kabupaten Minahasa Selatan.

2. Sebagai bahan informasi bagi pemerintah dalam mengambil kebijakan tentang manajemen kelompok tani.

3. Sebagai bahan informasi bagi pihak lain yang mau melanjutkan penelitian tentang manajemen kelompok tani.

\section{METODE PENELITIAN}

\section{Waktu dan Lokasi Penelitian}

Penelitian ini berlangsung selama 3 (tiga) bulan yaitu mulai bulan April sampai Juni 2017, di Desa Tewasen Kecamatan Amurang Barat Kabupaten Minahasa Selatan.

\section{Metode Pengambilan Sampel}

Populasi dalam penelitian ini yaitu semua anggota kelompok tani "Asi Endo" yang berjumlah 25 orang responden diambil seluruh anggota dalam kelompok tani termasuk didalamnya ketua, sekretaris dan bendahara.

\section{Metode Pengumpulan Data}

Metode yang digunakan dalam penelitian ini, yaitu metode survey. Data yang digunakan data primer yang diperoleh dari wawancara langsung dengan pengurus dan anggota kelompok tani berdasarkan daftar pertanyaan yang disiapkan serta hasil pengamatan secaara langsung atau survey di tempat penelitan.

\section{Konsep Pengukuran Variabel}

Variabel dalam penelitian ini adalah Identitas Kelompok Tani, Identitas Responden dan Fungsi Manajemen yang terdiri dari Fungsi Perencanaan, Fungsi Pengorganisasian, Fungsi Penggerakan, Fungsi Pengawasan dan Fungsi Penilaian.

1) Ketua

\section{Identitas Kelompok Tani}

2) Sekretaris

3) Bendahara

4) Tahun Berdiri Kelompok Tani

5) Jumlah Anggota Kelompok Tani

6) Jenis Usaha Tani Kelompok

\section{Identitas Responden}

1) Umur Responden

2) Jenis Kelamin

3) Jabatan Dalam Kelompok

4) Pekerjaan Responden

5) Pendidikan Responden

\section{Fungsi Manajemen}

a. Perencanaan (Planning)

Perencanaan adalah fungsi dasar manajemen dalam pembuatan pemikiran menjadi satu keputusan dan menentukan program yang harus disusun dimasa yang akan datang dalam rangka pencapaian tujuan yang telah ditentukan. Perencanaan diukur melalui 3 pernyatan sebagai berikut :

1) Rencana yang dibuat sesuai dengan yang ditetapkan sejak awal dalam kelompok.

- Pengolahan lahan

- Penggunaan saprodi

- Penggunaan benih

- Penggunaan tenaga kerja 


\section{- Pemasaran}

2) Semua kegiatan ada dalam daftar rencana.

3) Anggaran keuangan untuk setiap kegiatan sesuai dengan kegiatan yang dilakukan.

- Sumber modal

- Pembelian pupuk

- Biaya tenaga kerja

- Biaya sewa traktor

b. Pengorganisasian (Organizing)

Pengorganisasian adalah fungsi dari manajemen untuk pembagian tugas kerja yang akan dilakukan oleh setiap anggota kelompok berdasarkan profesi keahlian masing-masing anggota untuk mencapai tujuan. Pengorganisasian diukur melalui 5 pernyataan sebagai berikut:

1) Pembagian tugas sesuai dengan keahlian masing-masing.

2) Loyalitas setiap anggota dalam kelompok tani.

3) Keterlibatan setiap anggota dalam pengambilan keputusan.

4) Aturan yang dipakai dalam kelompok ditaati sesuai dengan ketentuan.

5) Informasi yang diberikan dalam setiap kegiatan kelompok selalu dijalankan.

c. Penggerakan (Motivating)

Penggerakan ialah keseluruhan proses pemberian motif bekerja kepada para bawahan sedemikan rupa sehingga mereka mau bekerja dengan ikhlas demi tercapainya tujuan organisasi dengan efisien dan ekonomis. Penggerakan diukur melalui 3 pernyataan sebagai berikut :

1) Memberikan semangat dan menumbuhkan motivasi sering dilakukan ketua kelompok.

2) Menumbuhkan kesadaran dan mengajak untuk selalu aktif dan berpartisipasi selalu dilakukan oleh sesama anggota kelompok maupun ketua kelompok.
3) Pelatihan dan bimbingan setiap anggota agar dapat memenuhi ukuran pelaksanaan

\section{d. Pengawasan (Controlling)}

Pengawasan ialah proses pengamatan dari pada pelaksanaan seluruh kegiatan organisasi untuk menjamin agar supaya semua pekerjaan yang sedang dilakukan berjalan sesuai dengan rencana yang telah ditentukan sebelumnya. Pengawasan diukur melalui 3 pernyataan sebagai berikut :

1) Monitor hasil-hasil pelaksanaan.

2) Pemecahan masalah setiap anggota terlebih dahulu diselesaikan.

3) Memberi sanksi kepada setiap anggota yang tidak taat aturan.

e. Penilaian (Evaluating)

Penilaian adalah proses pengukuran dan pembandingan hasil-hasil pekerjaan yang telah dicapai dengan hasil-hasil yang seharusnya dicapai. Penilaian diukur melalui 4 pernyataan sebagai berikut :

1) Ketua kelompok mengevaluasi setiap kegiatn yang dilakukan.

2) Kerja sama kelompok untuk mencapai tujuan.

3) Penyediaan fasilitas selama melakukan kegiatan.

4) Keberhasilan yang dicapai setiap anggota dalam memajukan kelompok.

\section{Metode Analisis Data}

Analisis data yang digunakan pada penelitian ini adalah analisis deskriptif, yang disajikan dalam bentuk tabel. Data yang dihasilkan dianalisis dengan menggunakan skala likert. Skala Likert (likert scale) adalah teknik pengukuran sikap yang paling luas dalam penelitian. Dalam skala likert, maka variabel yang diukur dijabarkan menjadi indikator variabel. Kemudian indikator tersebut dijadikan sebagai titik tolak untuk menyusun item-item instrumen berupa pernyataan-pernyataan. Dalam 
penelitian ini di susun 18 pertanyaan dengan total responden 25 orang. Jawaban setiap instrument yang menggunakan skala likert diberi skor 1-5, untuk membantu analisa data digunakan skor, Sangat Baik (skor 5), Baik (skor 4), Cukup baik (skor 3), Buruk (skor 2), Sangat Buruk (skor 1).

Memperoleh nilai total masingmasing variable adalah dengan menjumlahkan nilai-nilai dari item pernyataan dan kemudian dibagi dengan jumlah item pernyataan. Nilai variabel tersebut digolongkan dalam beberapa kategori yang didasarkan pada skala likert. Riduwan (2012).

Dengan cara perhitungan skor masingmasing pernyataan :

Jumlah skor tiap kriteria = capaian skor $\mathrm{X}$ jumlah responden.

Skor $5=5$ X $25=125$

Skor $4=4 \times 25=100$

Skor $3=3 \times 25=75$

Skor $2=2 \times 25=50$

Skor $1=1$ X $25=25$

Jumlah skor ideal untuk setiap pertanyaan (skor tertinggi) $=125$

Jumlah skor terendah $=25$

Dengan interpretasi nilai :

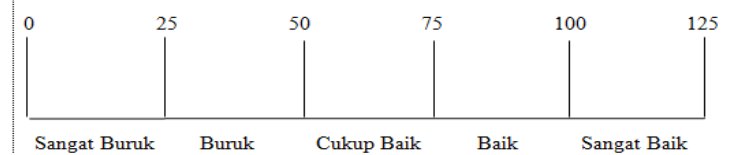

Gambar 1. Interpretasi Nilai Jumlah Skor Tiap Kriteria Pernyataan Cara perhitungan skor keseluruhan untuk mengetahui fungsi penerapan manajemen dalam kelompok tani

Jumlah skor seluruh kriterium = capaian jumlah skor $\mathrm{x}$ jumlah responden

Untuk :

Skor $5=5$ X 25 X $18=2250$

Skor $4=4$ X 25 X $18=1800$

Skor $3=3$ X $25 \times 18=1350$

Skor $2=2$ X 25 X $18=900$

Skor $1=1$ X 25 X $18=450$

Jumlah skor ideal untuk keseluruhan pernyataan $=2250$ (tertinggi)

Jumlah skor terendah $=450$ (terendah) Dengan interpretasi nilai :

$$
\begin{aligned}
& \frac{450}{2.250} \times 100 \%=20 \% \\
& \frac{900}{2.250} \times 100 \%=40 \% \\
& \frac{1.350}{2.250} \times 100 \%=60 \% \\
& \frac{1.800}{2.250} \times 100 \%=80 \% \\
& \frac{2.250}{2.250} \times 100 \%=100 \%
\end{aligned}
$$

Tingkat penerapan fungsi manajemen Jumlah Skor Hasil Pengumpulan Data

$$
=\overbrace{\text { Jumlah Skor Ideal (Tertinggi) }} \text { x100\% }
$$

Dengan interpretasi nilai :

Angka $0 \%-20 \%=$ Sangat Buruk

Angka 20\% - 40\% = Buruk

Angka 40\% - 60\% = Cukup Baik

Angka 60\% - 80\% = Baik

Angka 80\% - 100\% = Sangat Baik

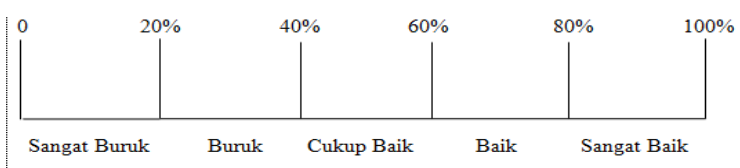

Gambar 2. Interpretasi Skor Penerapan Fungsi Manajemen

\section{HASIL DAN PEMBAHASAN}

\section{Gambaran Umum Lokasi Penelitian}

Desa Tewasen merupakan salah satu desa yang terletak di Kecamatan Amurang Barat Kabupaten Minahasa Selatan. Desa ini berdiri pada tanggal 25 Januari 1750 dan sudah dipimpin lebih dari 23 Kepala Desa/Hukum Tua dan terdiri dari 8 Jaga yang masing-masing dipimpin oleh kepala jaga. Luas wilayah Desa Tewasen terdiri dari pemukiman 2080 ha dan Ladang 19 ha. Saat ini Desa Tewasen dipimpin oleh Bpk. Janjte Masinambow sebagai Kepala Desa/Hukum Tua. Jumlah penduduk 1437 jiwa yang terdiri dari laki-laki 723 jiwa dan perempuan 714 jiwa dengan jumlah kepala keluarga $476 \mathrm{KK}$. Desa Tewasen berbatasan dengan :

- Sebelah Utara dengan Desa Kapitu

- Sebelah Timur dengan Desa Elusan

- Sebelah Selatan Desa Pondos

- Sebelah Barat Desa Tawaang

Penduduk asli desa Tewasen berasal dari suku Minahasa dan $100 \%$ beragama kristen 
dengan denominasi Protestan, Adven, dan Pantekosta. Tanaman yang diusahakan oleh penduduk desa ini yaitu tanaman kelapa, hortikultura dan buah-buahan.

\section{Tingkat Pendidikan}

Tingkat pendidikan penduduk Desa Tewasen, berdasarkan Tabel 1, tingkat pendidikan paling banyak adalah SMA/SMK sebanyak 382 jiwa (26,58\%), diikuti dengan SD sebanyak 364 jiwa (25,33\%), selanjutnya SMP sebanyak 298 jiwa $(20,74 \%)$, Perguruan Tinggi sebanyak 170, TK sebanyak 148 jiwa dan masih ada penduduk yang tidak sekolah sebanyak 75 jiwa.

Tabel 1. Tingkat Pendidikan Penduduk Desa Tewasen

\begin{tabular}{clrr}
\hline No. & $\begin{array}{c}\text { Tingkat } \\
\text { Pendidikan }\end{array}$ & $\begin{array}{c}\text { Jumlah } \\
\text { Penduduk } \\
\text { (Jiwa) }\end{array}$ & $\begin{array}{c}\text { Persentase } \\
(\%)\end{array}$ \\
\hline 1. & Tidak & 75 & 5,23 \\
2. & Sekolah & 148 & 10,29 \\
3. & Sekolah & 364 & 25,33 \\
4. & Dasar (SD) & & \\
5. & SMA & 298 & 20,74 \\
6. & Perguruan & 382 & 26,58 \\
& Tinggi & 170 & 11,83 \\
& & 1437 & 100,00 \\
\hline
\end{tabular}

Sumber: Kantor Desa Tewasen 2017

\section{Jenis Pekerjaan}

Berikut ini jenis pekerjaan penduduk Desa Tewasen yang didominasi sebagai petani kemudian sebagai pegawai swasta. Pegawai Negeri Sipil sebanyak 47 orang dan ada 1 orang sebagi dosen/tenaga pengajar di perguruan tinggi. Berdasarkan data Tabel 2, jenis pekerjaaan paling banyak adalah Petani sebesar 372 orang, dan paling sedikit adalah dosen dan TNI/Polri sebanyak 4 orang.

\section{Deskripsi Kelompok Tani Asi Endo}

Kelompok tani Asi Endo berada di Desa Tewasen Kecamatan Amurang Barat Kabupaten Minahasa Selatan. Kelompok tani ini berdiri dan dikukuhkan pada tanggal 12 Juli 2014 oleh Bpk. Jootje. S. Lengkey sebagai Kepala BP3K Kecamatan Amurang Barat, dan pada tanggal 10 Desember 2015 Kelompok Tani Asi Endo dikukuhkan sebagai Kelompok Tani Kelas Pemula. Usaha tani yang diusahakan kelompok tani ini yaitu tanaman jagung pembenihan yang merupakan program dari pemerintah dan semua hasil dari kegiatan ini dijual kepada pemerintah melalui PT. Pertani.

Adapun arti dari Asi Endo dalam bahasa daerah mau kemana nanti dibentuk oleh masyarakat Desa Tewasen melalui pemerintah desa dengan jumlah anggota sebanyak 25 orang dan kemudian dilakukan rapat pemilihan pengurus kelompok tani secara musyawarah dan terpilih sebagai ketua adalah Bapak Thamrin Kembuan, sekretaris Ibu Eflin Pondaag dan bendahara Bapak Jhoni Winerungan. Kelompok tani Asi Endo memiliki luas lahan sebesar 2.5 Ha. Pada saat penelitian dilakukan kelompok tani Asi Endo sedang menunggu panen tanaman jagung pembenihan.

Tabel 2. Jenis Pekerjaan Penduduk Desa Tewasen

\begin{tabular}{clr}
\hline No. & \multicolumn{1}{c}{ Jenis Pekerjaan } & Jumlah \\
\hline 1. & PNS & 47 \\
2. & Petani & 372 \\
3. & TNI/Polri & 4 \\
4. & Pegawai Swasta & 150 \\
5. & Buruh & 36 \\
6. & Sopir & 46 \\
7. & Dosen & 1 \\
8. & Perawat & 6 \\
9. & Wiraswasta & 35 \\
10. & Guru & 63 \\
\hline
\end{tabular}

\section{Karakteristik Responden}

\section{Karakteristik Responden Menurut Umur}

Tingkat umur mempengaruhi kemampuan seseorang dalam melakukan aktifitas maupun konsep berpikir seseorang, dalam penelitian ini yaitu anggota kelompok tani Asi Endo. Dari data primer yang diperoleh, jumlah responden berdasarkan 
umur dapat dilihat pada Tabel 3. Berdasarkan data Tabel 3 menunjukan bahwa umur responden pada interval $>60$ tahun memiliki nilai persentase sebesar $4 \%$ merupakan persentase nilai terkecil dengan 1 responden. Pada interval 31 - 40 tahun memiliki nilai persentase sebesar $44 \%$ ini merupakan persentase nilai terbesar dengan 11 responden, pada interval 21-30 tahun memiliki nilai persentase sebesar 24\% dengan 6 responden, pada interval 41 - 50 tahun memiliki nilai persentase $20 \%$ dengan 5 responden dan $51-$ 60 tahun memiliki nilai persentase sebesar $8 \%$ dengan 2 responden.

Tabel 3. Karakteristik responden berdasarkan kelompok umur

\begin{tabular}{ccrr}
\hline No. & $\begin{array}{c}\text { Umur } \\
\text { (Tahun) }\end{array}$ & $\begin{array}{c}\text { Jumlah } \\
\text { Responden } \\
\text { (Orang) }\end{array}$ & $\begin{array}{c}\text { Persentase } \\
(\%)\end{array}$ \\
\hline 1. & $21-30$ & 6 & 24 \\
2. & $31-40$ & 11 & 44 \\
3. & $41-50$ & 5 & 20 \\
4. & $51-60$ & 2 & 8 \\
5. & $>60$ & 1 & 4 \\
\hline & Jumlah & 25 & 100 \\
\hline
\end{tabular}

Sumber: Diolah Dari Data Primer (2017)

Hasil ini menunjukkan bahwa semua responden termasuk dalam kelompok umur atau usia tenaga kerja produktif yaitu dari 15 tahun 65 tahun. Dimana umur atau usia berpengaruh dalam setiap kegiatan yang dilakukan responden dalam kelompok tani untuk mencapai tujuan yang telah ditetapkan dengan melakukan penerapan fungsi manajemen.

\section{Karakteristik Responden Menurut Tingkat Pendidikan}

Semakin tinggi tingkat pendidikan seseorang semakin banyak pula pengetahuan atau wawasan yang dimiliki, baik itu menciptakan, menerapkan teknologi baru serta inovasi-inovasi yang baru. Dari hasil penelitian yang dilakukan tingak pendidikan responden dapat dilihat pada Tabel 4. Berdasarkan data Tabel 4 menunjukan bahwa tingkat pendidikan responden terbesar dengan nilai persentase $36 \%$ dengan banyaknya responden adalah 9 orang hanya sampai pada tingkat sekolah menengah atas, pada interval SD dan SMP memiliki nilai persentase yang sama yaitu $28 \%$ dengan masing-masing 7 responden dan yang memiliki nilai persentase terkecil yaitu $8 \%$ pada tingkat pendidikan D3 dan S1 dengan banyaknya responden hanya 2 orang.

Tabel 4. Karakteristik Responden Menurut Tingkat Pendidikan

\begin{tabular}{llrr}
\hline No. & $\begin{array}{c}\text { Tingkat } \\
\text { Pendidikan }\end{array}$ & $\begin{array}{c}\text { Jumlah } \\
\text { Responden } \\
\text { (Orang) }\end{array}$ & \multicolumn{1}{c}{$\begin{array}{c}\text { Persenta } \\
\text { se }(\%)\end{array}$} \\
\hline 1. & SD & 7 & 28 \\
2. & SMP & 6 & 28 \\
3. & SMA & 8 & 36 \\
4. & D3 dan S1 & 4 & 8 \\
\hline & Jumlah & 25 & 100 \\
\hline
\end{tabular}

Sumber : Diolah dari data primer 2017

\section{Karakteristik Responden Menurut Pekerjaan}

Pekerjaan merupakan tindakan seseorang yang selalu dilakukan berdasarkan keinginan diri sendiri untuk memenuhi kebutuhan kehidupannya. Dari hasil penelitian ini dapat dilihat pekerjaan responden baik itu pekerjaan utama dan juga pekerjaan sampingan dilihat pada Tabel 5.

Tabel 5. Karakteristik Responden Menurut Pekerjaan

\begin{tabular}{llrr}
\hline No. & $\begin{array}{c}\text { Jenis } \\
\text { Pekerjaan }\end{array}$ & $\begin{array}{c}\text { Jumlah } \\
\text { Responden } \\
\text { (Orang) }\end{array}$ & $\begin{array}{c}\text { Persentase } \\
(\%)\end{array}$ \\
\hline 1. & Petani & 19 & 76 \\
2. & Guru & 3 & 12 \\
3. & Buruh & 2 & 8 \\
4. & PNS & 1 & 4 \\
\hline & Jumlah & 25 & 100 \\
\hline
\end{tabular}

Sumber : Diolah dari data primer 2017

Berdasarkan data dalam Tabel 5 menunjukan bahwa dalam penelitian terdapat empat jenis pekerjaan dari responden selain sebagai anggota kelompok tani yaitu, petani, guru, buruh dan PNS. Petani merupakan pekerjaan terbanyak dari seluruh responden yaitu $76 \%$ dengan banyaknya responden 19 orang, sedangkan PNS dengan nilai persentase $4 \%$ merupakan 
pekerjaan terkecil dengan 1 responden dan guru memiliki nilai persentase sebesar $12 \%$ dengan 3 responden dan buruh memiliki nilai persentase $8 \%$ dengan 2 orang responden.

\section{Skor Rata-Rata Dan Interpretasi Nilai Penerapan Fungsi-Fungsi Manajemen}

Untuk mendeskripsikan penerapan fungsi manajemen, penilaian dilakukan terhadap unsur-unsur fungsi manajemen yang meliputi lima fungsi yaitu perencanaan, pengorganisasian, menggerakkan, pengawasan, dan evaluasi.

\begin{tabular}{|c|c|c|c|}
\hline \multirow{2}{*}{\multicolumn{2}{|c|}{$\begin{array}{lc}\text { Tabel 6. } & \text { Skor } \\
\text { Interpretasi } & \text { Nilai } \\
\text { Perencanaan } & \text { (Planning) } \\
\end{array}$}} & $\begin{array}{l}\text { Rata-Rata } \\
\text { Penerapan }\end{array}$ & $\begin{array}{r}\text { Dan } \\
\text { Fungsi }\end{array}$ \\
\hline & & & \\
\hline & $\begin{array}{c}\text { Fungsi } \\
\text { Perencanaan }\end{array}$ & $\begin{array}{l}\text { Total } \\
\text { Skor }\end{array}$ & Interpretasi \\
\hline 1. & $\begin{array}{lr}\text { Rencana } & \text { yang } \\
\text { dibuat } & \text { sesuai } \\
\text { dengan } & \text { yang } \\
\text { ditetapkan } & \text { sejak } \\
\text { awal } & \end{array}$ & 119 & $\begin{array}{l}\text { Sangat } \\
\text { Baik }\end{array}$ \\
\hline 2. & $\begin{array}{l}\text { Semua kegiatan } \\
\text { ada dalam daftar } \\
\text { rencana }\end{array}$ & 111 & $\begin{array}{l}\text { Sangat } \\
\text { Baik }\end{array}$ \\
\hline 3. & $\begin{array}{l}\text { Anggaran } \\
\text { keuangan sesuai } \\
\text { dengan kegiatan } \\
\text { yang } \\
\text { dilaksanakan }\end{array}$ & 96 & Baik \\
\hline & Jumlah & 326 & \\
\hline
\end{tabular}

Dalam Tabel 6 menunjukkan bahwa pernyataan fungsi perencanaan yang mendapatkan skor tertinggi adalah pernyataan "rencana yang dibuat sesuai dengan yang ditetapkan sejak awal" yang dimaksud disini adalah keseluruhan rencana kegiatan kerja atau program kerja (penyediaan lahan, bibit, proses penanaman sampai pemanenan) yang sudah ditetapkan sejak awal dalam kelompok tani Asi Endo di Desa Tewasen Kecamatan Amurang Barat Kabupaten Minahasa Selatan. Kemudian diikuti dengan pernyataan "semua kegiatan ada dalam daftar rencana" aktivitas kegiatan yang di maksud disini adalah kegiatan yang benar-benar ada dalam program kerja, seperti pengolahan lahan, penanaman, penyiangan, pemupukan dan pemanenan, serta yang terakhir ada "anggaran keuangan sesuai dengan kegiatan yang dilaksanakan" dana yang ada untuk menunjang (bantuan dana dan swadaya) setiap kegiatan agar dapat berjalan dengan baik seperti pembelian pupuk, biaya tenaga kerja dan biaya sewa traktor. Berdasarkan tabel 6 diperoleh skor rata-rata 108,66.

$$
\overline{\mathrm{x}}=\frac{\sum \mathrm{xi}}{\mathrm{n}}=\frac{326}{3}=108,66
$$

Interpretasi nilai penerapan fungsi perencanaan :

$$
\frac{326}{375} X 100 \%=86,93
$$

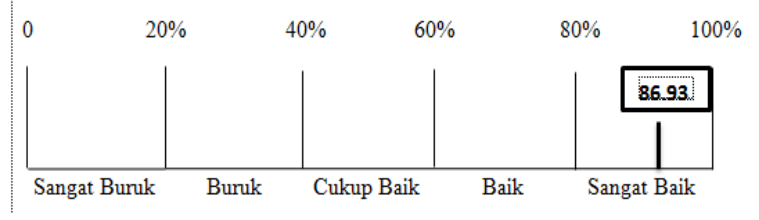

Gambar 3. Indeks Penerapan Fungsi Perencanaan

Hasil ini menunjukan bahwa penerepan fungsi perencanaan dalam kelompok tani Asi Endo berada pada titik 86,93 dengan interpretasi sangat baik.

Tabel 7 menunjukkan bahwa pernyataan fungsi pengorganisasian yang mendapatkan skor tertinggi adalah pernyataan "pembagian tugas sesuai keahlian" merupakan pembagian tugas kerja yang benar-benar sesuai dengan keahlian (Ketua, sekretaris, bendahara dan anggota) dalam kelompok tani Asi Endo, kemudian diikuti dengan pernyataan "keterlibatan anggota dalam pengambilan keputusan" dan "menjalankan informasi dalam setiap kegiatan" dimana setiap anggota benarbenar terlibat dalam setiap kebijakan untuk memperbaiki dan menangani setiap kendala yang dihadapi serta menerapkan informasiinformasi yang baru berupa inovasi dalam pelaksanaannya. 


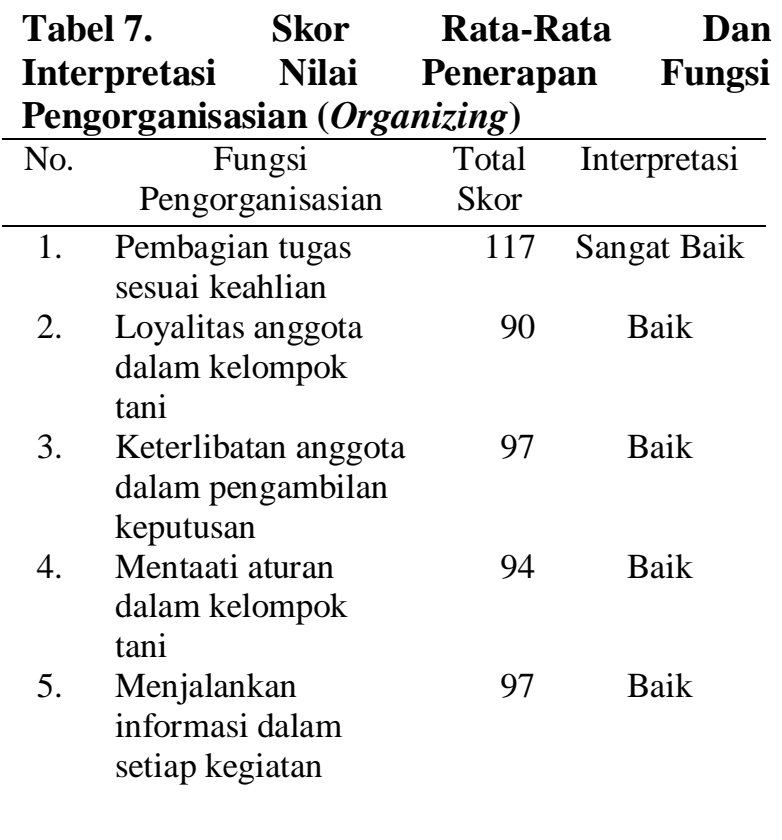

$\overline{\text { Jumlah }} 495$

Pernyataan selanjutnya yaitu "mentaati aturan dalam kelompok tani" aturan yang dimaksud disini adalah yang sudah ditentukan untuk dijadikan pedoman yang harus dipatuhi dan ditaati oleh setiap anggota kelompok seperti (mengumpulkan uang swadaya dari tiap anggota dan penjualan hasil produksi hanya di jual kepada PT. Pertani) serta yang terakhir ada "loyalitas anggota dalam kelompok tani" sikap setia dari setiap anggota terhadap kelompok tani tetap bekerja bersama-sama dalam keadaan apapun. Berdasarkan tabel 7 diperoleh skor rata-rata 99.

$$
\overline{\mathrm{x}}=\frac{\sum \mathrm{xi}}{\mathrm{n}}=\frac{495}{5}=99
$$

Interpretasi nilai penerapan fungsi pengorganisasian :

$$
\frac{495}{625} \times 100 \%=79,2
$$

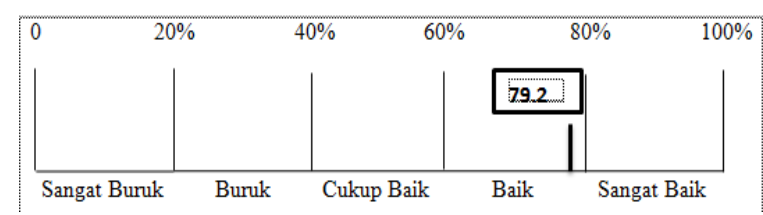

Gambar 4. Indeks Penerapan Fungsi Pengorganisasian

Hasil ini menunjukan bahwa penerapan fungsi pengorganisasian dalam kelompok tani Asi Endo berada pada titik 79,2 dengan

\begin{tabular}{|c|c|c|c|c|}
\hline \multicolumn{3}{|c|}{$\begin{array}{lc}\text { Tabel 8. } & \text { Skor } \\
\text { Interpretasi } & \text { Nilai } \\
\text { Penggerakan } & \text { (Motivating }\end{array}$} & $\begin{array}{l}\text { Rata-Rata } \\
\text { Penerapan }\end{array}$ & $\begin{array}{r}\text { Dan } \\
\text { Fungsi }\end{array}$ \\
\hline No. & $\begin{array}{r}\mathrm{F} \\
\text { Peng }\end{array}$ & $\begin{array}{l}\text { ngsi } \\
\text { gerakan }\end{array}$ & $\begin{array}{l}\text { Total } \\
\text { Skor }\end{array}$ & Interpretasi \\
\hline 1. & $\begin{array}{l}\text { Ketua k } \\
\text { membe } \\
\text { semang } \\
\text { motivas }\end{array}$ & $\begin{array}{l}\text { lompok } \\
\text { kan } \\
\text { t dan }\end{array}$ & 107 & $\begin{array}{c}\text { Sangat } \\
\text { Baik }\end{array}$ \\
\hline 2. & $\begin{array}{l}\text { Sesama } \\
\text { aktif } \\
\text { menum } \\
\text { kesadar } \\
\text { berpart }\end{array}$ & $\begin{array}{l}\text { anggota } \\
\text { uhkan } \\
\text { n } \\
\text { ipasi }\end{array}$ & 108 & $\begin{array}{c}\text { Sangat } \\
\text { Baik }\end{array}$ \\
\hline 3. & $\begin{array}{l}\text { Pelatih } \\
\text { bimbin } \\
\text { memen } \\
\text { pelaksa }\end{array}$ & $\begin{array}{l}\text { dan } \\
\text { an } \\
\text { hi ukuran } \\
\text { aan }\end{array}$ & 106 & $\begin{array}{c}\text { Sangat } \\
\text { Baik }\end{array}$ \\
\hline & & nlah & 321 & \\
\hline
\end{tabular}
interpretasi baik.
Tabel 8 menunjukkan bahwa pernyataan fungsi penggerakan yang mendapatkan skor tertinggi adalah pernyataan "sesama anggota aktif menumbuhkan kesadaran berpartisipasi" yang dimaksud disini adalah kesadaran yang timbul pada diri sendiri dan memberikan dampak pada anggota kelompok yang lain untuk bisa berpartisipasi dalam kegiatan kelompok , kemudian diikuti dengan pernyataan "ketua kelompok memberikan semangat dan motivasi" dorongan oleh ketua terhadap setiap anggota kelompok agar tetap semangat bekerja sama dalam mencapai tujuan yang sudah di tetapkan bersama (pada setiap pertemuan yang dilakukan).

Pernyataan yang terakhir yaitu "pelatihan dan bimbingan memenuhi ukuran pelaksanaan" dimana setiap anggota mengikuti penyuluhan dan bimbingan teknis untuk menambah pengetahuan dari anggota kelompok tani agar bisa tercapai tujuan dari kelompok tani. Berdasarkan tabel 8 diperoleh skor rata-rata 107.

$$
\overline{\mathrm{x}}=\frac{\sum \mathrm{xi}}{\mathrm{n}}=\frac{321}{3}=107
$$

Interpretasi nilai penerapan fungsi penggerakan :

$$
\frac{321}{375} \times 100 \%=85,6
$$




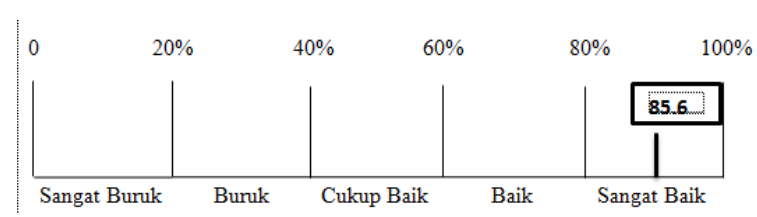

Gambar 5. Indeks Penerapan Fungsi Penggerakan

Hasil ini menunjukan bahwa penerapan fungsi penggerakan dalam kelompok tani Asi Endo berada pada titik 85,6 dengan interpretasi sangat baik.

Tabel 9. Skor Rata-Rata Dan Nilai Penerapan Fungsi Pengawasan (Controling)

\begin{tabular}{clcc}
\hline No. & \multicolumn{1}{c}{$\begin{array}{c}\text { Fungsi } \\
\text { Pengawasan }\end{array}$} & $\begin{array}{c}\text { Total } \\
\text { Skor }\end{array}$ & Interpretasi \\
\hline 1. & $\begin{array}{l}\text { Monitor hasil- } \\
\text { hasil pelaksanan } \\
\text { Kerja sama } \\
\text { kelompok untuk } \\
\text { mencapai tujuan }\end{array}$ & 120 & $\begin{array}{c}\text { Sangat } \\
\text { Baik } \\
\text { Baik }\end{array}$ \\
3. & $\begin{array}{l}\text { Sanksi kepada } \\
\text { anggota yang } \\
\text { tidak taat aturan }\end{array}$ & 84 & Baik \\
\hline \multicolumn{1}{c}{ Jumlah } & 298 & \\
\hline
\end{tabular}

Tabel 9 menunjukkan bahwa pernyataan fungsi pengawasan yang mendapatkan skor tertinggi adalah pernyataan "monitor hasil-hasil pelaksanaan" yang dimaksud disini adalah penyuluh dan ketua melakukan pengawasan terhadap setiap kegiatan yang dilakukan serta menilai kinerja dari setiap anggota kelompok tani, kemudian diikuti dengan pernyataan "kerja sama kelompok untuk mencapai tujuan" dimana dibutuhkan kebersamaan atau rasa sepenanggungan yang terjalin dalam kelompok dari setiap anggota.

Pernyataan yang terakhir yaitu "sanksi kepada anggota yang tidak taat aturan" dimana teguran atau sikap tegas dari ketua selaku pengurus untuk memberikan sanksi terhadap anggota yang tidak taat aturan sesuai dengan aturan yang berlaku. Berdasarkan tabel 9 diperoleh skor rata-rata 99,33.

$\overline{\mathrm{x}}=\frac{\sum \mathrm{xi}}{\mathrm{n}}=\frac{298}{3}=99,33$

Interpretasi nilai penerapan fungsi pengawasan :

$$
\frac{298}{375} X 100 \%=79,46
$$

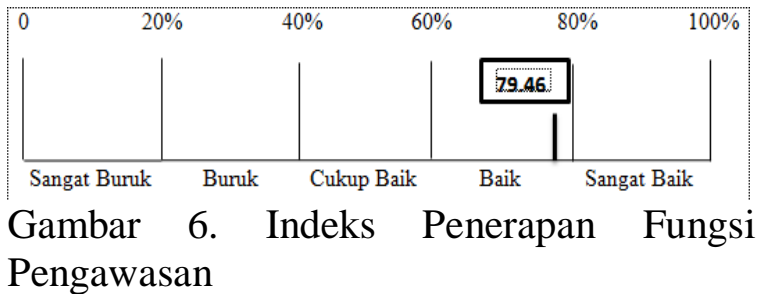

Hasil ini menunjukan bahwa penerepan fungsi pengawasan dalam kelompok tani Asi Endo berada pada titik 79,46 dengan interpretasi baik.

Tabel 10. Skor Rata-Rata Dan Nilai Penerapan Fungsi Penilaian (Evaluating)

\begin{tabular}{clcc}
\hline No. & Fungsi Penilaian & $\begin{array}{l}\text { Total } \\
\text { Skor }\end{array}$ & Interpretasi \\
\hline 1. & $\begin{array}{l}\text { Ketua kelompok } \\
\text { mengevaluasi setiap } \\
\text { kegiatan yang } \\
\text { dilakukan }\end{array}$ & 113 & Sangat Baik \\
2. & $\begin{array}{l}\text { Pemecahan masalah } \\
\text { terlebih dahulu } \\
\text { diselesaikan }\end{array}$ & 91 & Baik \\
3. & $\begin{array}{l}\text { Fasilitas yang } \\
\text { tersedia dalam } \\
\text { kegiatan }\end{array}$ & 101 & Sangat Baik \\
Keberhasilan setiap \\
anggota dalam \\
memajukan \\
kelompok
\end{tabular}

Tabel 10 menunjukkan bahwa pernyataan fungsi penilaian yang mendapatkan skor tertinggi adalah pernyataan "keberhasilan setiap anggota dalam memajukan kelompok" yang dimaksud disini adalah hasil yang diperoleh dari semua kegiatan yang sudah dilakukan sesuai dengan yang direncanakan dari awal, kemudian diikuti dengan pernyataan "ketua kelompok mengevaluasi setiap kegiatan yang dilakukan" keaktifan ketua dalam mengecek kegiatan yang sudah dilaksanakan serta pernyataan "fasilitas yang tersedia selama kegiatan" dimana memberikan kebutuhan berupa alat-alat kerja seperti traktor alat pengolah tanah dan sprayer atau alat penyemprot untuk tumbuhan.

Pernyataan yang terakhir yaitu "pemecahan masalah terlebih dahulu diselesaikan" bentuk kebersamaan setiap anggota agar masalah yang ada terselesaikan dan tidak mengganggu tanggung jawab 
untuk mencapai tujuan kelompok. Berdasarkan Tabel 10 diperoleh skor ratarata 105,7 .

$$
\overline{\mathrm{x}}=\frac{\sum \mathrm{xi}}{\mathrm{n}}=\frac{423}{4}=105,7
$$

Interpretasi nilai penerapan fungsi penilaian

$$
\frac{423}{500} X 100 \%=84,6
$$

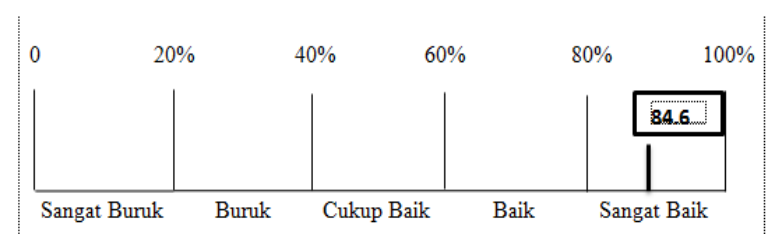

Gambar 7. Indeks Penerapan Fungsi Penilaian

Hasil ini menunjukan bahwa penerepan fungsi penilaian dalam kelompok tani Asi Endo berada pada titik 84,6 dengan

\begin{tabular}{|c|c|c|c|c|}
\hline \multicolumn{2}{|c|}{$\begin{array}{l}\text { Tabel } 11 \\
\text { Manajemen,Total } \\
\text { dan Interpretasi } \mathbf{N}\end{array}$} & \multicolumn{2}{|c|}{$\begin{array}{l}\text { Rekapitulasi } \\
\text { kor, Indeks } \\
\text { ai }\end{array}$} & $\begin{array}{r}\text { Fungsi } \\
\text { enerapan }\end{array}$ \\
\hline No & $\begin{array}{c}\text { Fungsi } \\
\text { Manajemen }\end{array}$ & $\begin{array}{l}\text { Total } \\
\text { Skor }\end{array}$ & $\begin{array}{l}\text { Indeks } \\
\text { Penerap } \\
\text { an }(\%)\end{array}$ & Interpretasi \\
\hline 1. & Perencanaan & 326 & 86,93 & Sangat Baik \\
\hline 2. & $\begin{array}{l}\text { Pengorganisa- } \\
\text { sian }\end{array}$ & 495 & 79.2 & Baik \\
\hline 3. & Penggerakan & 321 & 85,6 & Sangat Baik \\
\hline 4. & Pengawasan & 298 & 79,46 & Baik \\
\hline 5. & Penilaian & 423 & 84,6 & Sangat Baik \\
\hline
\end{tabular}
interpretasi sangat baik.

Dalam Tabel 11 tentang rekapitulasi fungsi manajemen,total skor, indeks penerapan dan interpretasi nilai menunjukkan bahwa penerapan fungsi manajemen kelompok tani Asi Endo di Desa Tewasen yang paling tinggi ada pada fungsi perencanaan, kemudian fungsi penggerakan, fungsi penilaian, fungsi pengorganisasian dan paling rendah ada pada fungsi pengawasan.

Cara untuk mengetahui penerapan fungsi manajemen dalam kelompok tani Asi Endo di Desa Tewasen Kecamatan Amurang
Barat Minahasa Selatan, dihitung jumlah keseluruhan skor pada setiap kriterium dan sesuai hasil penelitian skor mencapai 1.863. Dalam penelitian ini jumlah skor ideal 2.250 (kategori tertinggi) dan jumlah skor terendah yaitu 450. Berdasarkan data yang dihimpun dari 18 pernyataan yang diajukan kepada 25 orang responden, diperoleh total skor 1.863. Secara persentase, angka indeks penerapan fungsi manajemen dalam kelompok tani Asi Endo di Desa Tewasen sebagai berikut :

Penerapan Fungsi Manajemen

$$
\begin{aligned}
& =\frac{\text { Jumlah skor hasil pengumpulan data }}{\text { Jumlah skor ideal (tertinggi) }} \times 100 \% \\
& =\frac{1.863}{2.250} \times 100 \%=82,8 \%
\end{aligned}
$$

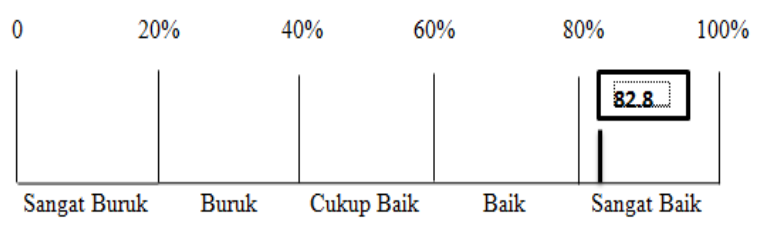

Gambar 8. Indeks Penerapan Fungsi Manajemen

Berdasarkan hasil analisis menggunakan skala likert, indeks penerapan fungsi manajemen dalam kelompok tani Asi Endo di Desa Tewasen berada pada titik $82,8 \%$ dan tergolong dalam kategori sangat baik. Hal ini berarti bahwa kelompok tani Asi Endo di Desa Tewasen memiliki penerapan fungsi manajemen yang sangat baik yaitu fungi perencanaan, fungsi pengorganisaian, fungsi penggerakan, fungsi pengawasan dan fungsi penilaian

\section{KESIMPULAN DAN SARAN}

\section{Kesimpulan}

Penerapan fungsi manajemen kelompok tani Asi Endo di Desa Tewasen Kecamatan Amurang Barat Kabupaten Minahasa Selatan yang meliputi fungsi perencanaan, fungsi pengorganisasian, fungsi menggerakan, fungsi pengawasan dan fungsi penilaian. Secara keseluruhan berada pada kategori Sangat Baik dengan hasil $82.8 \%$. Artinya anggota kelompok bersama dengan pengurus kelompok sangat baik 
dalam menerapkan fungsi manajemen dalam kelompok tani Asi Endo.

\section{Saran}

Saran dalam penelitian ini yaitu penerapan fungsi manajemen kelompok tani Asi Endo harus dipertahankan baik itu fungsi perencanaan, fungsi pengorganisasian, fungsi penggerakan, fungsi pengawsan dan fungsi penilaian. Supaya kelompok tani Asi endo tetap menjadi kelompok tani yang berkembang atau bisa menjadi kelompok tani yang lebih maju dan menjadi panutan bagi kelompok tani lain yang ada di Desa Tewasen bahkan desa-desa yang ada di Kabupaten Minahasa Selatan.

\section{DAFTAR PUSTAKA}

BP4K. 2015. Peran Penting Kelompok Tani dalam Pembangunan. BP4K Mejuji Kabupaten Temanggung Jawa Tengah.

Erwadi, Doli. 2012. Peran Penyuluh Pertanian dalam Mengaktifkan Kelompok Tani Di Kecamatan Lubuk Alung. Universitas Andalas. Padang.

Hakam, A., 2014. Peran kelompok tani terhadap usaha peningkatan pendapatan anggota melalui Program Kemitraan Usahatani, Vol. 27, Malang.

Handoko, T,H. 2012. Manajemen Personalia Dan Sumberdaya Manusia. Edisi ke2.Cetakan ke-19.Yogyakarta : BPFE

Hasibuan, M,S,P. 2011. Manajemen : Dasar, Pengertian dan Masalah. Edisi Revisi.Cetakan ke-9.Jakarta : BPFE.

Hermanto. 2007. Rancangan Kelembagaan Tani dalam Implementasi Prima Tani di Sumatera Selatan. Jurnal Analisis Kebijakan Pertanian. Vol 5.

Karyoto. 2016. Dasar-Dasar Manajemen (Teori, Definisi dan Konsep). Andi Offset. Yogyakarta.

Makawekes, N. 2016. Dinamika Kelompok Tani Cempaka di Kelurahan Meras Kecamatan Bunaken Kota Manado. Skripsi Fakultas Pertanian Universitas Sam Ratulangi Manado.
Mardikanto, T. 2009. Sistem Penyuluhan Pertanian. Universitas Sebelas Maret. Surakarta.

Mariani. 2012. Manajemen Kelompok Tani Petani Sayuran dalam Mendukung Kesehatan Pangan Kota Banjarbaru. Jurnal Agribisnis Perdesaan Vol. 02 No. 04 Tahun 2012. Fakultas Pertanian Universitas Lambung Mangkurat.

Mutmainah. R. 2014. Peran Kepemimpinan Kelompok Tani dan Efektifitas Pemberdayaan Petani. Skripsi Institusi Pertanian Bogor.

Nuryanti dan Swatika. 2011. Peran Kelompok Tani dalam Penerapan Teknologi Pertanian.

Rauf, R dan Rusli Munaf. 2015. Lembaga Kemasyarakatan di Indonesia. Zanafa Publishing. Yogyakarta.

Ridhotullah, S dan Jauhar, M. 2015. Pengantar Manajemen. Jakarta Prestasi Pustaka.

Riduwan. 2012. Rumus dan Data Dalam Analisis Statistika. Penerbit Alphabet. Bandung.

Sadono D. 2008. Pemberdayaan Petani: Paradigma Baru Penyuluhan Pertanian di Indonesia.IPB.Jurnal Penyuluhan Maret 2008, Vol. 4 No. 1

Siagian, Sondang P. 2015. Filsafat Administrasi. Jakarta :Bumi Aksara.

Suwandi, A. 2006. Administrasi Penyuluhan. Universitas Terbuka Jakarta.

Terry, G,R dan Rue, L,W. 2009. Dasar-dasar Manajemen. Cetakan ke-11. Jakarta: Bumi Aksara.

Winardi, 2009. Asas-Asas Manajemen. Penerbit Mandar Maju, Bandung. 